\title{
Phosphorus leaching from riparian soils with differing management histories under three grass species
}

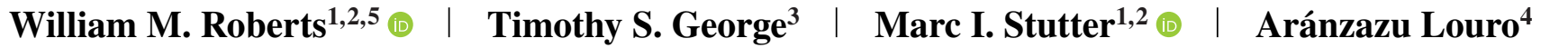 \\ Mustafa Ali $^{1}$ | Philip M. Haygarth ${ }^{1}$ (i)
}

${ }^{1}$ Lancaster Environment Centre, Lancaster

Univ., Lancaster, LA1 4YQ, UK

${ }^{2}$ The James Hutton Institute, Aberdeen, AB15 $8 \mathrm{QH}, \mathrm{UK}$

${ }^{3}$ The James Hutton Institute, Dundee, DD2 5DA, UK

${ }^{4}$ Rothamsted Research, North Wyke, Okehampton, Devon, EX20 2SB, UK

${ }^{5}$ Current address: Univ. of Chichester Business School, Bognor Regis Campus, Upper Bognor Rd., Bognor Regis, West Sussex, PO21 1HR, UK

\section{Correspondence}

William M. Roberts, Univ. of Chichester Business School, Bognor Regis Campus, Upper Bognor Rd., Bognor Regis, West Sussex, PO21 1HR, UK.

Email:w.roberts@chi.ac.uk

Funding information

Natural Environment Research Council, Grant/Award Number: NE/GO12571/1

Assigned to Associate Editor Wei Zheng.

\begin{abstract}
Plants release carbon-based exudates from their roots into the rhizosphere to increase phosphorus $(\mathrm{P})$ supply to the soil solution. However, if more $\mathrm{P}$ than required is brought into solution, additional $\mathrm{P}$ could be available for leaching from riparian soils. To investigate this further, soil columns containing a riparian arable and buffer strip soil, which differed in organic matter contents, were sown with three common agricultural and riparian grass species. The $\mathrm{P}$ loads in leachate were measured and compared with those from unplanted columns, which were $0.17 \pm 0.01$ and $0.89 \pm 0.04 \mathrm{mg} \mathrm{kg}^{-1}$ for the arable and buffer strip soil, respectively. A mixture of ryegrass and red fescue significantly $(p \leq .05)$ increased dissolved inorganic $\mathrm{P}$ loads in leachate from the arable $\left(0.23 \pm 0.01 \mathrm{mg} \mathrm{kg}^{-1}\right)$ and buffer strip soil $\left(1.06 \pm 0.05 \mathrm{mg} \mathrm{kg}^{-1}\right)$, whereas barley significantly reduced $\mathrm{P}$ leaching from the buffer strip soil $\left(0.53 \pm 0.08 \mathrm{mg} \mathrm{kg}^{-1}\right)$. This was dependent on the dissolved organic $\mathrm{C}$ released under different plant species and on interactions with soil management history and biogeochemical conditions, rather than on plant uptake of $\mathrm{P}$ and accumulation into biomass. This suggested that the amount and forms of P present in the soil and the ability of the plants to mobilize them could be key factors in determining how plants affect leaching of soil P. Selecting grass species for different stages of buffer strip development, basing species selection on root physiological traits, and correcting soil nutrient stoichiometry in riparian soils through vegetative mining could help to lower this contribution.
\end{abstract}

\section{1 | INTRODUCTION}

Diffuse pollution remains a major threat to surface waters due to eutrophication caused by nutrient transfers originating, in part, from agricultural land (Carpenter et al., 1998; Le Moal et al., 2019; Zhang, Collins, Murdoch, Lee, \& Naden, 2014). A large proportion of catchment nutrient loads comes

\footnotetext{
Abbreviations: DIP, dissolved inorganic phosphorus; DOC, dissolved organic carbon; DON, dissolved organic nitrogen; DOP, dissolved organic phosphorus; TDN, total dissolved nitrogen; TDP, total dissolved phosphorus.
}

from agricultural areas where high nutrient sources, a high potential for mobilization from those sources and transport pathways that allow delivery to surface waters coincide (i.e., "critical source areas") (Lemunyon \& Gilbert, 1993; Pionke, Gburek, Sharpley, \& Schnabel, 1996). Delivery of nutrients from these areas can be reduced by establishing vegetated buffer strips in the downslope riparian zone by ceasing cultivation, fertilizer application, and grazing. The shallowing slopes of the riparian zone and the denser vegetation cover slow overland flow and encourage nutrient-laden water to infiltrate and leach through the soil profile. Particulate phosphorus (P) forms are deposited on or within the soil, 
and dissolved $\mathrm{P}$ forms can become absorbed to the soil itself (Dorioz, Wang, Poulenard, \& Trévisan, 2006; Hoffmann, Kjaergaard, Uusi-Kämppä, Hansen, \& Kronvang, 2009). However, several studies have observed elevated dissolved P in leachate, shallow groundwater, and overland flow leaving buffer strip soils compared with upslope managed soils (Dupas et al., 2015; Ulén \& Etana, 2010; Uusi-Kämppä, 2005), and the exact mechanisms responsible remain unclear (Hoffmann et al., 2009; Roberts, Stutter, \& Haygarth, 2012).

Leaching involves the eluviation of solutes through soils (Haygarth \& Sharpley, 2000). However, despite numerous P leaching studies involving agricultural plants, it remains difficult to isolate the effects of plant roots based on the current literature. Studies involving plants have often used simulated rainfall, which incorporates the effects of stems and leaves (Riddle \& Bergstrôm, 2013), or have been conducted without an unplanted treatment for comparison (Newman et al., 2009; Sovik \& Syversen, 2008). Where only total P in leachate is measured, changes in the dissolved $\mathrm{P}$ forms that result from the leaching process may have been masked (Fraser, Carty, \& Steer, 2004; Marrs, Gough, \& Griffiths, 1991; Syversen \& Haarstad, 2005).

The presence of plant roots in the soil generally reduces $\mathrm{N}$ leaching. Plants withdraw $\mathrm{N}$ directly from the soil solution, where it is present in sufficient concentrations to meet plant needs via passive uptake (Richardson, Barea, McNeill, \& Prigent-Combaret, 2009a; Scherer-Lorenzen, Palmborg, Prinz, \& Schulze, 2003). Plants also withdraw P exclusively from the soil solution (in the form of orthophosphate). However, due to the strong geochemical fixation of $\mathrm{P}$ within the soil, the supply of $\mathrm{P}$ to the soil solution is typically too low to meet plant needs (Bieleski, 1973; Hinsinger, 2001; Schachtman, Reid, \& Ayling, 1998; Turner, Baxter, \& Whitton, 2003). A key way in which plants meet their need for $P$ is by influencing the mobilization of soil $\mathrm{P}$ into the soil solution through the production and release of carbon (C)-based exudates from the roots into the rhizosphere soil (Kuzyakov \& Domanski, 2000; Richardson, Hocking, Simpson, \& George, 2009b; Walker, Bais, Grotewold, \& Vivanco, 2003). Plants release exudates, such as organic acids and enzymes, that can solubilize P from mineral surfaces and mineralize organically complexed phosphate, respectively. Exudates can also be metabolized by the microbial biomass, thereby increasing microbial activity. This can increase $\mathrm{P}$ mobilization into soil solution through a range of mechanisms and/or cause inorganic $\mathrm{P}$ to become immobilized within the microbial biomass in organic form (Dinkelaker, Mheld, \& Marschner, 1989; Hinsinger, 2001; Richardson et al., 2009a). Even though farmers apply fertilizer to increase the supply of $\mathrm{P}$ to the soil solution, plants still release exudates, albeit sometimes at lower rates (Lyu et al., 2016; Ratnayake, Leonard, \& Menge, 1978). If by the action of its roots, a plant mobilizes more soil $\mathrm{P}$ into solution than it needs or has the ability to take up during growth, then excess $\mathrm{P}$ could

\section{Core Ideas}

- Mobilization of soil P by plants could contribute to P leaching.

- The presence of plant roots either increased or reduced $P$ leaching.

- The leaching was related to dissolved organic C released under plants.

- Leaching was also dependent on species interactions with soil conditions.

- The results indicate a range of potential options for managing this leaching.

be available for leaching. Indeed, several studies have reported the accumulation of soluble inorganic and organic $\mathrm{P}$ fractions in rhizosphere soils (Grinsted, Hedley, White, \& Nye, 1982; Kirk, Santos, \& Findenegg, 1999a, 1999b).

The amount of $\mathrm{P}$ mobilized by plants and the need or ability for P uptake by plants varies greatly and is dependent on factors such as plant species and soil biogeochemical conditions. For example, plant species release different exudates that may be more or less effective in a given soil, and plants can mobilize more $\mathrm{P}$ into soil solution in soils with large P contents and solubility (Hinsinger \& Gilkes, 1995, 1996, 1997). Buffer strip soils often have a higher proportion of total and soluble $\mathrm{P}$ in organic form compared with field soils (Roberts et al., 2013; Stutter et al., 2015), which may favor mobilization by species that specialize in mineralizing these organic forms. Furthermore, buffer strips are often established on soils with high $\mathrm{P}$ levels that are further elevated by $\mathrm{P}$ inputs from upslope, meaning that there is more likely to be excess $\mathrm{P}$ mobilization by plants. In terms of $\mathrm{P}$ uptake by plants and accumulation into biomass, some plant species naturally require more P than others (McDowell, Sharpley, Crush, \& Simmons, 2011; Räty, Uusi-Kämppä, Yli-Halla, Rasa, \& Pietola, 2010), so they could reduce the soil solution $\mathrm{P}$ available for leaching to a lower level. Furthermore, plant requirements for $\mathrm{P}$ uptake are often suppressed under $\mathrm{N}$ limitation, which is common in terrestrial habitats (Bracken et al., 2015; Elser et al., 2007). Nevertheless, the elevated organic matter contents in buffer strip soils could act as source of plant-available $\mathrm{N}$, which could enhance $\mathrm{P}$ uptake and accumulation into plant biomass (Baligar, Fageria, \& He, 2001; Blevins, Thomas, \& Cornelius, 1977; Mazzoncini et al., 2016). It is therefore likely to be a fine balance between $P$ mobilization and uptake by plants that determines how $\mathrm{P}$ leaching is affected.

To investigate this further, an analog model of the plantsoil system was established in a glasshouse leaching experiment (i) to compare $\mathrm{C}, \mathrm{N}$, and $\mathrm{P}$ leaching under a range of grass species during growth against an unplanted soil; (ii) to identify how these differences vary in riparian arable and 
buffer strip soils of the same type but with differing biogeochemical conditions; and (iii) to determine whether plant $\mathrm{P}$ uptake and accumulation into biomass or $\mathrm{C}$ release in the soils determines the magnitude of $\mathrm{P}$ leaching under the range of grasses. It is hoped that achieving these objectives will improve understanding of the mechanisms of plant-mediated soil $\mathrm{P}$ cycling with different plants and of the buffer stripspecific factors of changing soil conditions on $\mathrm{P}$ leaching interactions with plants involved.

\section{2 | MATERIALS AND METHODS}

\section{1 | Treatment and experimental design}

Two soils were collected from the toe of a hillslope (5\% slope) at Newton Rigg Agricultural College, Cumbria, UK (54.664 $\mathrm{N},-2.798^{\circ} \mathrm{W}$ ). The field on the hillslope was under continuous spring barley (Hordeum vulgare L.), with conventional tillage for $3 \mathrm{yr}$ prior to sampling and as part of an oilseed rape (Brassica napus L.) and winter barley rotation for $5 \mathrm{yr}$ prior to that. Fertilizers were applied to match annual crop offtakes, which were $\sim 22 \mathrm{~kg} \mathrm{P} \mathrm{ha}^{-1}$ for spring barley. Overland flow from the upslope barley field passes through a 6-m-wide riparian buffer strip before reaching the adjacent stream. The buffer strip was established 8 yr prior to sampling by ceasing tillage and using annual topping to control weed growth. One soil was collected from the rooting zone $(0-7 \mathrm{~cm}$ depth) at three points in the center of the buffer strip parallel to the field edge and bulked. Another soil was collected (also 0-7 cm depth) at three adjacent points $3 \mathrm{~m}$ upslope of the buffer strip within the arable field and bulked. Both soils have a sandy silt loamy texture (25\% sand, $58 \%$ silt, and $17 \%$ clay), making them suitable for both arable and livestock farming (Collins et al., 2012; Soil survey of England and Wales, 1983). This allowed the effects of plant roots on $\mathrm{P}$ leaching to be compared between riparian soils of the same type and total $\mathrm{P}$ contents but with significantly higher organic matter contents, water holding capacity, microbial biomass $\mathrm{P}$, and $\mathrm{P}$ solubility in the buffer strip soil (Supplemental Table S1). Soils were dried at $25^{\circ} \mathrm{C}$ for $7 \mathrm{~d}$. Soil drying is one of the most common abiotic perturbations experienced by soils, especially during plant growth in spring (Blackwell et al., 2010), and drying of this intensity is likely to become more frequent under climate change (Forber et al., 2017). The arable soil was then sieved to $6 \mathrm{~mm}$. This gave a similar structure to the fine tilth achieved in the field by harrowing earlier in the year. The buffer strip soil was treated in the same way so that results were comparable.

Fifty polyvinyl chloride columns ( $7 \mathrm{~cm}$ wide, $30 \mathrm{~cm}$ high) covered at the bottom end by 1-mm-gauge nylon mesh were packed with $2 \mathrm{~cm}$ of gravel $(5-10 \mathrm{~mm}$ diameter) to prevent soil washout. Twenty-five of the columns were packed with $800 \mathrm{~g}$ of the arable soil, and 25 columns were packed with
$800 \mathrm{~g}$ of the buffer strip soil. This was done to achieve a bulk density of $1 \mathrm{~g} \mathrm{~cm}^{-3}$ to reflect the low bulk density measured at the site after spring tillage for arable cropping or buffer strip establishment (Roberts, 2013). Five replicates of the following plant treatments were applied to the columns for both soils separately: unplanted control, perennial ryegrass (Lolium perenne L.), red fescue (Festuca rubra L.), a 50:50 mixture of ryegrass and red fescue, and spring barley. Ryegrass and barley are both widespread in UK agricultural systems, and ryegrass and red fescue are among the most common grasses found in UK riparian buffer strips (Collins et al., 2012; Cope \& Gray, 2009). This allowed comparisons in P leaching between grasses present in buffer strips and those present under and adapted to arable cultivation. Furthermore, it allows comparisons between plants of different $\mathrm{P}$ uptake, because these species show contrasting P uptake and accumulation into biomass when grown in P-enriched soils (Brown et al., 2018).

Seeds were germinated on agar plates, and the seedlings were transferred to the columns. A total of two seedlings per column for barley and six for all other plant treatments were transferred to achieve plant densities similar to those in the arable field and buffer strip, respectively. One week prior to transferring seedlings, the dried soils in the columns were rewetted gradually to prevent leachate and maintained at $60 \%$ water holding capacity throughout the experiment by daily weighing and addition of deionized water. All treatments were kept in a completely randomized design within a temperaturecontrolled greenhouse $\left(18^{\circ} \mathrm{C}\right.$ day and $14^{\circ} \mathrm{C}$ nighttime temperature) with $\sim 16 \mathrm{~h}$ of daylight supplemented with artificial lighting to maintain a minimum light intensity of $200 \mu \mathrm{mol}$ quanta $\mathrm{m}^{-2} \mathrm{~s}^{-1}$ to represent spring/summer growth conditions.

\section{$2.2 \mid$ Column leaching and sampling}

Columns were leached with a simulated runoff solution five times between 45 and $75 \mathrm{~d}$ after germination, which is the period when all plants were displaying high growth rates. To simulate the runoff solution, eroded sediments collected from traps on the mid-slope of the field were air dried at $25^{\circ} \mathrm{C}$ for $7 \mathrm{~d}$, and subsamples of $0.34 \mathrm{~g}$ were dispersed in $250 \mathrm{ml}$ of deionized water on a reciprocating shaker for $1 \mathrm{~h}$ prior to each leaching cycle. This resulted in the following mean $\mathrm{P}$ concentrations across all five leaching cycles $\left(\mathrm{mg} \mathrm{L} \mathrm{L}^{-1}\right)$ : total particulate $\mathrm{P}, 0.36 \pm 0.04$; dissolved inorganic $\mathrm{P}$ (DIP), $0.08 \pm 0.006$; and dissolved organic $\mathrm{P}(\mathrm{DOP}), 0.008 \pm 0.002$. Phosphorus concentrations were low to reflect those found in overland flow originating from the mid-slope during a spring storm as measured in a barley field at Newton Rigg (Roberts, 2013). The volume applied to each column was large $(250 \mathrm{ml})$ to mimic spring/summer overland flow, generated under 
infiltration excess conditions (Peukert, Griffith, Murray, Macleod, \& Brazier, 2014, 2016), entering buffer strips via concentrated flow paths and infiltrating into the buffer strip soil. The solutions were applied to the columns in 50-ml increments, without excessive ponding and contact with stems, to total the $250 \mathrm{ml}$ over $1 \mathrm{~h}$. Plastic beakers collected leachate from the columns, which were then weighed to determine leachate volumes and calculate accumulated P loads. Five days prior to the final leaching cycle, $25 \mathrm{ml}$ of $\mathrm{N}$ solution (2.5 $\mathrm{M} \mathrm{NH}_{4} \mathrm{SO}_{4}, 400 \mathrm{mM} \mathrm{CaNO}_{3}$, and $400 \mathrm{mM} \mathrm{KNO}_{3}$ ) was applied to each column to relieve the developing $\mathrm{N}$ limitation that had been noted in the absence of legumes and/or chemical fertilizer application. This was to avoid grasses being $\mathrm{N}$ stressed on analysis of plant $\mathrm{P}$ at the end of the experiment.

\section{3 | Laboratory analysis}

The leachate samples were filtered to $<0.45 \mu \mathrm{m}$ within $1 \mathrm{~h}$ of each leaching cycle. Filtrates were analyzed for dissolved molybdate reactive $\mathrm{P}$ (a proxy for DIP), nitrate $\left(\mathrm{NO}_{3}{ }^{-} \mathrm{N}\right)$, and ammonium $\left(\mathrm{NH}_{4}{ }^{+}-\mathrm{N}\right)$. After an automated digestion procedure, filtrates were analyzed for total dissolved N (TDN), total dissolved P (TDP), and dissolved organic C (DOC) by colorimetry. These were all performed according to the manufacturer's instructions (San++). Dissolved organic N (DON) and dissolved unreactive $\mathrm{P}$ (a proxy for DOP) were determined by difference as DON $=\mathrm{TDN}-\left(\mathrm{NO}_{3}-\mathrm{N}+\mathrm{NH}_{4}-\mathrm{N}\right)$ and DOP $=$ TDP - DIP. Detection limits were $1 \mu \mathrm{g} \mathrm{L}^{-1}$ for DIP and TDP and 1.0, 0.1, and $0.5 \mathrm{mg} \mathrm{L}^{-1}$ for $\mathrm{NO}_{3}{ }^{-}-\mathrm{N}, \mathrm{NH}_{4}{ }^{+}-\mathrm{N}$, and DOC, respectively.

After the completion of all leaching cycles, plants were removed from the columns, washed in deionized water, and separated into roots and shoots. The different fractions were oven dried at $60^{\circ} \mathrm{C}$ for $5 \mathrm{~d}$ or until constant weight was achieved, weighed, and milled. The resulting milled samples were digested in concentrated nitric acid and hydrogen peroxide solution prior to determination of $\mathrm{P}$ concentration by malachite green colorimetry (Irving \& McLaughlin, 1990).

\section{4 | Statistics}

All statistical analyses were performed using R statistical software (version 3.2.2) with the nlme and Lme4 packages (Bates, 2010; Pinheiro, Bates, DebRoy, \& Sarkar, 2007). A mixedeffects linear model was used to identify statistically significant differences and interactions between treatments in concentration and nutrient ratio data. The analysis was performed with soil and plant as fixed factors and with leaching cycle as a random factor and included interactions between fixed factors. Fixed-effects linear modeling was used for the same pur- pose on data for accumulated loads and plant $\mathrm{P}$ contents data, and was conducted using soil and plant as fixed factors and included interaction terms.

Linear modeling was used to determine the effect of covariates, specifically DOC release and plant $\mathrm{P}$ uptake and accumulation into biomass, on DIP concentrations in leachate. However, the temporal replication in concentration data was averaged away to better match the structure of the plant $\mathrm{P}$ data (resulting in $n=50$ ). This was performed based on the aforementioned soil and plant factors with the addition of covariates: DOC concentration and root, shoot and plant total $\mathrm{P}$ contents. This analysis was also repeated with the substitution of DIP and DOC concentrations for the corresponding accumulated loads.

The fits of all models were investigated in plots of residuals versus fitted values to ensure assumptions were met. Results were considered significant when probability values were $\leq .05$. Because of highly significant interactions in the data sets, those interactions and simple effects, rather than main effects, were reported.

\section{3 | RESULTS}

\section{1 | Leaching of carbon, nitrogen, and phosphorus forms}

Overall means and standard errors for nutrient concentrations leached under the different plants grown in each of the two soils are presented in Table 1. With the exception of red fescue growing in the arable field soil, DOC concentrations were increased by the presence of plant roots (Table 1), with greater increases observed in the buffer strip soil (plant-soil interaction: $p<.001$ ). Plants always reduced leaching of $\mathrm{N}$ forms, but reductions in $\mathrm{NO}_{3}{ }^{-}-\mathrm{N}$ were greater and more significant under the plants growing in the buffer strip soil, whereas reductions in DON by plants were greater and more significant in the arable soil (Table 1) (plant-soil interactions: both $p<.05)$.

When growing in the arable field soil, ryegrass and the mixture significantly increased mean DIP concentrations ( $p=.05$ and $p=.009$, respectively) to levels above those of the unplanted control (Table 2). However, in the buffer strip soil, it was red fescue and the mixture that elevated mean DIP concentrations ( $p=.005$ and $p=.002$, respectively) whereas barley reduced mean concentration $(p<.001$; plant-soil interaction: $p<.001)$. In addition to an overall decline in DIP concentrations at the fifth leaching, the differences in DIP concentrations leached under the different treatments began to diminish in both soils (Figure 1). Despite differences in leachate volumes between plant treatments, accumulated loads of $\mathrm{P}$ fractions followed the same patterns as those found in the concentration data (Table 1). 
T A B L E 1 Means and standard errors for determinant concentrations and accumulated P loads in leachate samples for the different plants grown in the arable field soil and the buffer strip soil

\begin{tabular}{|c|c|c|c|c|c|}
\hline Sample characteristics ${ }^{a}$ & Unplanted & Ryegrass & Red fescue & Mixture & Barley \\
\hline & \multicolumn{5}{|l|}{ Arable field soil } \\
\hline Leachate volume, $\mathrm{ml}$ & $221 \pm 9$ & $214 \pm 7$ & $219 \pm 11$ & $219 \pm 5$ & $203 \pm 10$ \\
\hline $\mathrm{DOC}, \mathrm{mg} \mathrm{L}^{-1}$ & $6.5 \pm 0.7$ & $8.5 \pm 0.8^{*}$ & $6.5 \pm 0.6$ & $9.0 \pm 0.9^{*}$ & $10.6 \pm 1.6^{*}$ \\
\hline $\mathrm{NO}_{3}{ }^{-}-\mathrm{N}, \mathrm{mg} \mathrm{L}^{-1}$ & $33.1 \pm 3.1$ & $16.2 \pm 2.8^{* *}$ & $23.2 \pm 8.5^{*}$ & $19.7 \pm 4.5^{* *}$ & $10.2 \pm 3.2^{* * *}$ \\
\hline DIP, $\mathrm{mg} \mathrm{kg}^{-1}$ & $0.17 \pm 0.01$ & $0.20 \pm 0.02$ & $0.17 \pm 0.02$ & $0.23 \pm 0.01 * *$ & $0.14 \pm 0.01$ \\
\hline DOP, $\mathrm{mg} \mathrm{L}^{-1}$ & $0.03 \pm 0.01$ & $0.03 \pm 0.01$ & $0.02 \pm 0.01$ & $0.03 \pm 0.01$ & $0.04 \pm 0.01^{*}$ \\
\hline \multirow[t]{2}{*}{$\mathrm{DOP}, \mathrm{mg} \mathrm{kg}^{-1}$} & $0.04 \pm 0.012$ & $0.03 \pm 0.005$ & $0.02 \pm 0.001$ & $0.03 \pm 0.005$ & $0.05 \pm 0.007$ \\
\hline & \multicolumn{5}{|l|}{ Buffer strip soil } \\
\hline $\mathrm{NO}_{3}{ }^{-}-\mathrm{N}, \mathrm{mg} \mathrm{L}^{-1}$ & $24.9 \pm 1.6$ & $5.0 \pm 1.1^{* * *}$ & $11.5 \pm 2.2^{* *}$ & $5.5 \pm 1.3^{* * *}$ & $2.8 \pm 0.7^{* * *}$ \\
\hline $\mathrm{DON}, \mathrm{mg} \mathrm{L}^{-1}$ & $4.6 \pm 0.3$ & $2.9 \pm 0.2^{*}$ & $3.0 \pm 0.3^{*}$ & $3.1 \pm 0.6^{*}$ & $3.7 \pm 0.3^{*}$ \\
\hline DIP, $\mathrm{mg} \mathrm{L}^{-1}$ & $0.69 \pm 0.03$ & $0.81 \pm 0.05$ & $0.89 \pm 0.05^{* *}$ & $0.97 \pm 0.05^{* *}$ & $0.45 \pm 0.03 * * *$ \\
\hline DIP, $\mathrm{mg} \mathrm{kg}^{-1}$ & $0.89 \pm 0.04$ & $0.84 \pm 0.06$ & $1.02 \pm 0.05$ & $1.06 \pm 0.05^{*}$ & $0.53 \pm 0.08^{*}$ \\
\hline DOP, $\mathrm{mg} \mathrm{L}^{-1}$ & $0.12 \pm 0.02$ & $0.19 \pm 0.01 * *$ & $0.11 \pm 0.02$ & $0.10 \pm 0.01$ & $0.14 \pm 0.01$ \\
\hline DOP, $\mathrm{mg} \mathrm{kg}^{-1}$ & $0.16 \pm 0.012$ & $0.20 \pm 0.018$ & $0.14 \pm 0.008$ & $0.1164 \pm 0.006$ & $0.168 \pm 0.026$ \\
\hline
\end{tabular}

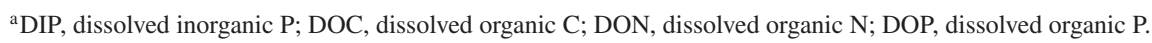

${ }^{*}$ Significant at the .05 probability level. ${ }^{* *}$ Significant at the .01 probability level. ${ }^{* * *}$ Significant at the .001 probability level.

T A B L E 2 Means and standard errors for nutrient ratios based on concentrations in leachate samples for the different plants grown in the arable field soil and the buffer strip soil

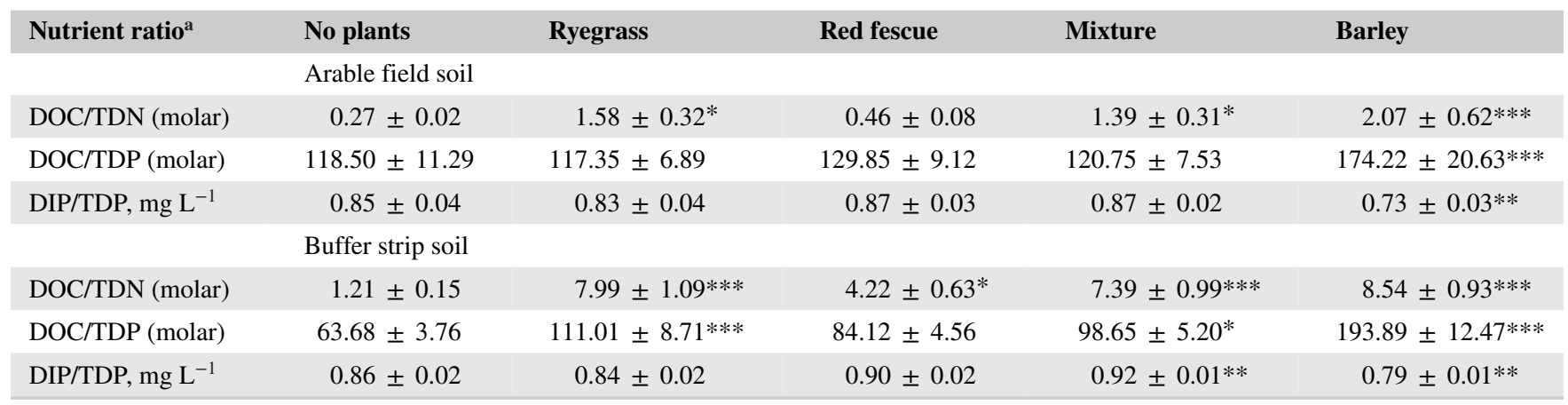

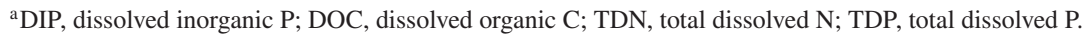

${ }^{*}$ Significant at the .05 probability level. ${ }^{* *}$ Significant at the .01 probability level. ${ }^{* * *}$ Significant at the .001 probability level.

Plant treatments had little impact on mean concentrations of DOP, except for barley, which increased mean concentration in the arable soil $(p=.04)$, and ryegrass, which significantly $(p=.01)$ elevated mean concentrations in the buffer strip soil relative to the unplanted controls (Table 1).

Overall means and standard errors for nutrient ratios in leachate from different plant treatments within each soil are presented in Table 2. For unplanted columns, the arable soil had a significantly lower DOC/TDN ratio and a signif- icantly higher DOC/TDP ratio in leachate than the buffer strip soil $(p<.001)$ (Table 2$)$. Nutrient ratios were also affected by the presence of plant roots, with roots generally increasing DOC/TDN and DOC/TDP ratios in leachate relative to the unplanted soil (Table 2). Barley caused the greatest increases in both ratios in both soils. The mixture increased the DIP/TDP ratio in the buffer strip soil, whereas barley reduced the DIP/TDP ratio in leachate from both soils relative to the unplanted soil (Table 2). 


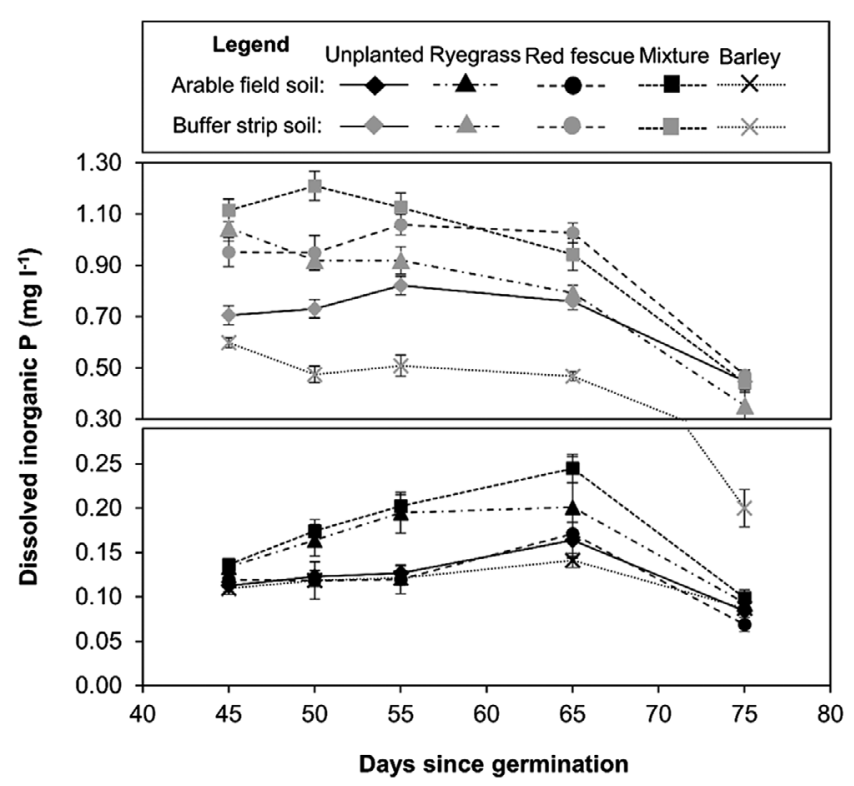

F I G U RE 1 Means and SEM $(n=5)$ for dissolved inorganic P concentrations (with axis break at $0.299 \mathrm{mg} \mathrm{L}^{-1}$ ) in leachate from the different plants grown in the two soils measured at $45,50,55,65$, and $75 \mathrm{~d}$ after germination when all plants were displaying high growth rates. Nitrogen solution was applied at Day 70 to relieve any developing $\mathrm{N}$ limitation in the plants

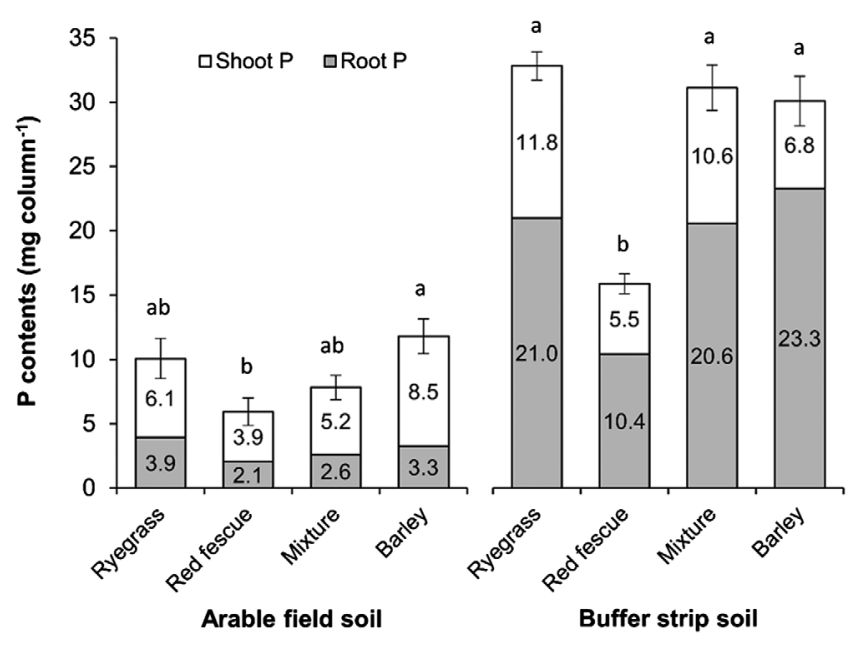

F I G URE 2 Means and $\operatorname{SEM}(n=5)$ for the total P contents of plants grown in each of the two soils showing the contribution of root and shoot P. Different letters between plant treatments within each soil indicate a significant difference in means at $p \leq .05$ as determined by linear modeling

\section{2 | Effects of dissolved organic carbon and plant phosphorus contents on phosphorus leaching}

Means and standard errors for the $\mathrm{P}$ contents of plants grown in each of the two soils are shown in Figure 2. In the arable soil, only barley and red fescue had significantly different $\mathrm{P}$

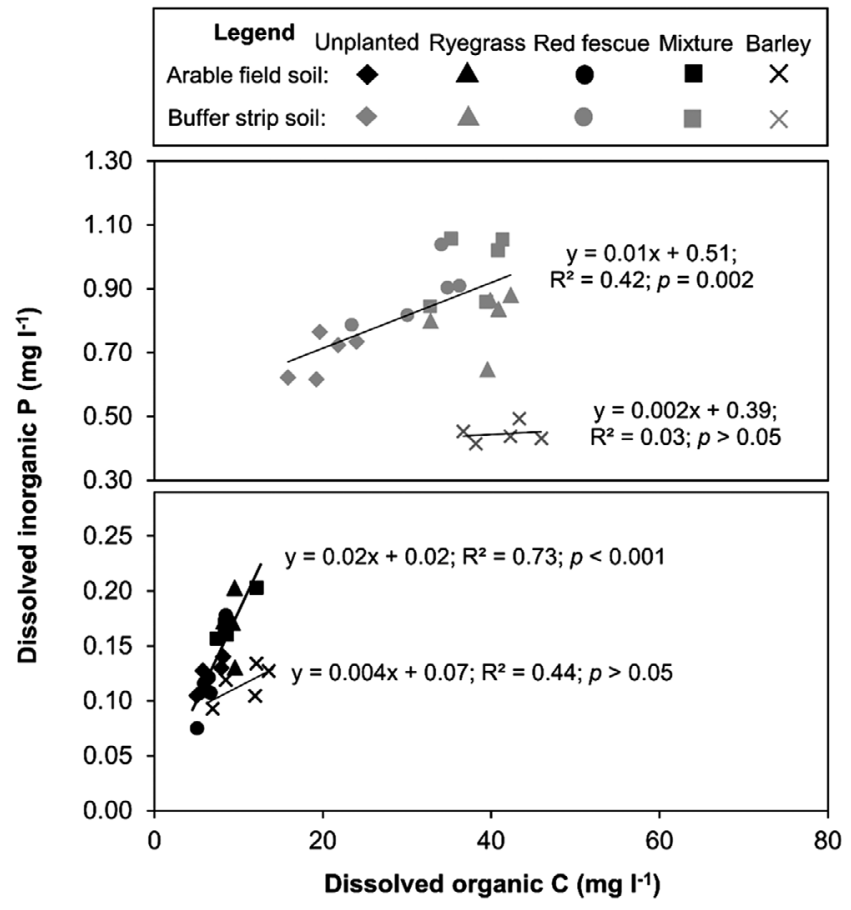

F I G U R E 3 Relationships between dissolved inorganic $\mathrm{P}$ and dissolved organic $\mathrm{C}$ concentration (with axis break at $0.299 \mathrm{mg}$ DIP L ${ }^{-1}$ ) isolated based on analysis of covariance. Regression statistics are for unplanted, ryegrass, red fescue, and the mixture data combined and for barley separately in each of the two soils

contents, with barley containing more P (Figure 2). In the buffer strip soil, ryegrass, the mixture, and barley showed significantly greater $\mathrm{P}$ uptake and accumulation into biomass than red fescue. The greater differences in $\mathrm{P}$ contents between the plants growing in the buffer strip soil compared with those growing in the arable soil meant that the soil-plant interaction was significant $(p=.02)$. In both soils, plant $\mathrm{P}$ contents were positively correlated with plant biomass (both $r=.9$ and $p<.001$ ) (see Supplemental Tables S2 and S3).

When the DIP data were analyzed with DOC concentration and root, shoot, and plant total P included as covariates, the model explained $98 \%$ of variance in DIP concentration and indicated that DOC concentration was a significant $(t=2.5$; $p=.01)$ factor in explaining DIP concentrations. In both soils, barley resulted in the lowest slope values and the highest intercept values, which were significantly different from those of the other plant treatments $(p<.05)$. The same model, but with loads instead of concentrations, explained $97 \%$ of variance in DIP load and identified DOC load as being a significant $(t=4.6 ; p<.001)$ factor in explaining DIP load. Neither root, shoot nor plant $\mathrm{P}$ contents had an effect on DIP concentrations or loads, so they were removed from both models with no significant impact on Akaike's information criterion. The individual relationships between DIP and DOC concentrations separated on the basis of this analysis are shown in Figure 3. 


\section{4 | DISCUSSION}

To explore the effects of plant roots on P leaching, this study quantified nutrient leaching under a range of grass species that were selected based on their widespread use in UK agriculture. The use of the arable and buffer strip soils meant that the leaching experiment was conducted on soils that had elevated organic matter content and water holding capacity in the buffer strip soil. The differences showed that total P did not differ and that agronomic soil P status (via Olsen P) was high in both soils but only slightly greater in the field soil. However, altered $\mathrm{P}$ cycling in the higher-C buffer strip soil led to significantly greater microbial biomass $\mathrm{P}$ and water-soluble $\mathrm{P}$ than the field soil. Such indicators of labile $\mathrm{P}$ turnover and potential for leaching being greater in adjacent buffer than arable soils (based on the same parent materials) have been previously reported (Roberts et al., 2013; Stutter \& Richards, 2012). Furthermore, buffer strip soils have greater organic matter and microbial biomass $\mathrm{P}$, and therefore buffer strip soils are more susceptible to $\mathrm{P}$ release after tillage and drying-rewetting cycles (Blackwell et al., 2010; Gu et al., 2018), which were simulated in this study. As a combined result of these factors, leachate $\mathrm{P}$ concentrations and loads were highest from the buffer strip soil.

Elevated DOC leaching under plants, as observed in this study, is thought to be mainly derived from root exudates but also from elevated microbial activity and decomposition (Jones, Nguyen, \& Finlay, 2009; Martin, 1971). Consistent reductions in $\mathrm{N}$ leaching under plants, as also seen here, have been attributed to removal of $\mathrm{NO}_{3}{ }^{-}-\mathrm{N}$ by plant roots directly from the soil solution and, in the case of DON, to enzymatic mineralization of soluble organic $\mathrm{N}$ (Leimer, Oelmann, Wirth, $\&$ Wilcke, 2015; Scherer-Lorenzen et al., 2003). However, the greater reductions in DON leaching under the plants growing in the arable soil could indicate greater mineralization rates than in the buffer strip soil. Indeed, high rates of $\mathrm{N}$ mineralization have been shown in previous studies to be at least partly related to low substrate $\mathrm{C} / \mathrm{N}$ (Lovett, Weathers, \& Athur, 2002; Scherer-Lorenzen et al., 2003), and the unplanted arable soil had significantly lower DOC/TDN in leachate than the unplanted buffer strip soil. Mineralized DON can also contribute to $\mathrm{NO}_{3}{ }^{-}-\mathrm{N}$ leaching (Leimer et al., 2015), and the lesser reduction in $\mathrm{NO}_{3}{ }^{-}-\mathrm{N}$ leaching from the arable field soil could further support the idea of increased mineralization.

Through their roots, different plants species showed contrasting effects on $\mathrm{P}$ leaching, with perennial grasses tending to increase and barley tending to reduce $\mathrm{P}$ leaching. This finding is supported by several studies investigating how rootinduced rhizosphere $\mathrm{pH}$ change affects $\mathrm{P}$ solubility. Although these studies noted soluble $\mathrm{P}$ accumulations in rhizosphere soils compared with unplanted soils and attributed this to reductions in $\mathrm{pH}$, however even in such fine-scale experi- ments the exact cause was difficult to isolate due to the complexity of the rhizosphere (Grinsted et al., 1982; Hinsinger, Gobran, Gregory, \& Wenzel, 2005; Kirk et al., 1999a, 1999b). Indeed, in this study leachate measurements indicated an overall increase in $\mathrm{pH}$ of the soil solution, probably due to $\mathrm{OH}^{-} / \mathrm{HCO}^{-3}$ release from roots associated with nitrate uptake.

In this study, suppression of the effects of roots and the overall decline in $\mathrm{P}$ concentrations at the fifth leaching cycle could be due to several factors. These may include recovery of the soil from drying and disturbance during conditioning of the soil and forming of the columns, the addition of $\mathrm{N}$ due to signs of limitation, and/or maturation of the grasses and reduction in root activity. All of these factors could reduce soil solution $\mathrm{P}$ and/or increase competition for P (Addiscott \& Thomas, 2000; Blackwell et al., 2010; Gu et al., 2018; Rowe et al., 2016; Selles et al., 2011).

The effects of plant roots on P leaching varied between the soils originally sourced from locations that differed in soil management history and associated biogeochemical conditions. The conditions brought about by the buffer strip soil promoted plant biomass and $\mathrm{P}$ accumulation into it. Despite this, the presence of ryegrass roots appeared to elevate DIP concentrations in leachate from the arable soil only, whereas red fescue roots appeared to cause more $\mathrm{P}$ leaching from the buffer strip soil, despite accumulating more $\mathrm{P}$. When growing together, ryegrass and red fescue elevated DIP loads from both soils, which may have been driven by the concentration increases caused by ryegrass in the arable soil and by red fescue in the buffer strip soil. However, concentrations and loads of DIP were always greater under the mixtures than under the monocultures, which could indicate interactions between the two species in the access to $\mathrm{P}$ fractions and forms (Brooker et al., 2015; Giles et al., 2017; Hinsinger et al., 2011).

In both soils, the DOC released under perennial grasses was related to DIP leaching. Because the majority of DOC released under plants is thought to be derived from root exudates, this relationship could indicate that C-based exudates (e.g., organic acids and enzymes) were directly mobilizing $\mathrm{P}$ by solubilization of $\mathrm{P}$ from mineral surfaces and/or by mineralization of organic P. However, a proportion of this DOC and DIP will also result indirectly from increased microbial activity and associated $\mathrm{P}$ mobilization mechanisms under plants. The potential mechanisms are numerous and could range from microbes releasing $\mathrm{P}$ from organic matter as they increase decomposition to situations where labile $\mathrm{C}$ fuels microbes to lower oxygen conditions, leading to redox-related $\mathrm{P}$ release from $\mathrm{Fe}$ oxides. For the former mechanism, the fact that soil $\mathrm{C} / \mathrm{P}$ and leachate DOC/TDP ratios were low would support the idea that $\mathrm{P}$ is preferentially mineralized or mobilized during decomposition because higher threshold ratios ranging from 200 to 300 have been suggested (Stutter et al., 2015). Regardless of uncertainty around the mechanisms involved, 
even finer-scale rhizosphere studies have measured depletions in the immediate vicinity of ryegrass roots and accumulations further away (Hinsinger \& Gilkes, 1996; Hinsinger et al., 2005). This indicates that plants can influence $P$ solubility outside the rhizosphere where they do not have the ability to take up $\mathrm{P}$ and where there is a risk of $\mathrm{P}$ leaching.

As further indicated by the analysis of covariance, the DOC released under barley appeared to differ strongly in its effects on $\mathrm{P}$ leaching compared with the DOC released under perennial grasses. Although no indicators of DOC quality were measured, the analysis of covariance results could indicate that barley exuded a different quality of DOC that either mobilized $\mathrm{P}$ less effectively or resulted in increased immobilization of $\mathrm{P}$ within the microbial biomass (Menezes-Blackburn et al., 2016; Richardson et al., 2009b). Indeed, the reduction in DIP/TDP in leachate under barley indicates P immobilization, and this is further supported by the DOC/TDP ratios nearing 200 under barley. This situation could be associated with the breeding of barley for inorganic $\mathrm{P}$ replete conditions and loss in its ability to control the availability of $\mathrm{P}$ by exudation or to control priming of the microbial biomass as seen when comparing modern barley varieties with wild ones (Mwafulirwa et al., 2016). When taken together, these results suggest that the amount and forms of $\mathrm{P}$ present in the soil and the ability of the plants to mobilize them could be key factors in determining how plants affect $\mathrm{P}$ leaching through their roots.

At least in the short-term during plant growth, the roots of the perennial grasses could therefore contribute to the reported increase in $\mathrm{P}$ leaching from riparian buffer strip soils (Ulén \& Etana, 2010; Uusi-Kämppä, 2005). With buffer strips being highly connected to the stream through hydrology and proximity, any $\mathrm{P}$ mobilized by roots could potentially be delivered to the stream. This could occur when rainfall or overland flow that has infiltrated into the buffer strip soil moves vertically to shallow groundwater or horizontally to the stream as shallow subsurface flows through buffer strip surface soils. If leached $\mathrm{P}$ is adsorbed to the subsoil, remobilization and delivery could occur at a later date, for example by microbial Fe reduction stimulated by anaerobic conditions when shallow groundwater saturates surface soils (Dupas et al., 2015; Roberts et al., 2012). However, despite potentially increasing $\mathrm{P}$ leaching in some instances, by increasing DOC and reducing $\mathrm{N}$ leaching, plants tended to improve the overall stoichiometry of nutrients leaching from the soil and pushed ratios toward more optimal ones for microbial rather than algal assimilation in the receiving waterbody (Godwin \& Cotner, 2015; Stutter, Graeber, Evans, Wade, \& Withers, 2018). Nevertheless, this could be pushed further through appropriate management.

During the initial establishment of buffer strips, the contribution of plant roots to leaching from buffer strips could be minimized by planting with red fescue or species with similar root physiological traits. As organic matter builds up due to no-tillage, the buffer strip could be reseeded with ryegrass or species with similar root physiological traits. However, intensive tillage for reseeding, as simulated in this study through the sieving of soil, can increase organic matter decomposition and the release of dissolved P (Addiscott \& Thomas, 2000; Butler \& Haygarth, 2007). As such, practices such as no tillage, minimum tillage or over-seeding may be preferable. Including species with similar root physiological traits to barley could actually reduce $P$ leaching. The effects of plant roots on P leaching in this study were observed under enriched soil $\mathrm{P}$ conditions according to Olsen $\mathrm{P}$ soil testing. One approach to reducing these effects may therefore be to reduce soil $\mathrm{P}$ levels by vegetative mining (i.e., by cutting and removing vegetation along with the nutrients contained in the biomass). This is in contrast to the current system in the United Kingdom, where buffer strips are either left unmanaged or are topped to control weed growth. Vegetative mining can reduce soil $\mathrm{P}$ levels and leaching over varying timescales depending on a range of factors including soil $\mathrm{P}$ levels, soil biogeochemical conditions, and plant species used (Hille et al., 2018; Rowe et al., 2016; Schulte et al., 2010). This study shows that plants can accumulate as much as twice the amount of $\mathrm{P}$ into aboveground biomass and effectively accelerate $\mathrm{P}$ drawdown when growing in the conditions after buffer strip establishment.

\section{5 | CONCLUSION}

The results presented in this study show that, through the action of their roots, plants have the potential to either elevate or reduce $\mathrm{P}$ leaching under the experimental conditions used. This was dependent on DOC released under different plant species and the on the interactions with soil management history and biogeochemical conditions rather than on plant uptake of $\mathrm{P}$ and accumulation into biomass. These findings support the hypothesis that if a plant mobilizes more soil $\mathrm{P}$ than it needs or has the ability to take up during growth, then excess $\mathrm{P}$ will be available for leaching.

Because these effects were suppressed at the end of the experiment, future studies could look in more detail at interactions with soil moisture regimes and soil disturbance as plants and plant communities mature. This would help determine if these effects only occur immediately after tillage for buffer strip establishment or if they are reoccurring with soil drying and rewetting or plant growth and maturation cycles.

If future studies find that, through the action of their roots, plants make a significant contribution to leaching losses under more natural field conditions, then options for mitigating this risk could be further explored. Options include using different plant species at different stages of buffer strip development; identifying and using plants with similar root physiological traits to barley; and correcting soil C, N, and P stoichiometry in buffer strip soils through vegetative mining. 


\section{CONFLICT OF INTEREST}

The authors declare no conflict of interest.

\section{ACKNOWLEDGMENTS}

This work was supported by NERC Grant GO12571. The authors thank Lancaster University and the James Hutton Institute for providing access to resources; Yvonne Cook, Lawrie Brown, Bruna Arruda, Joice Heidemann, Jaleh BahriEsfanhani, and Patrick Keenan for providing laboratory assistance; and three anonymous reviewers for their valuable feedback on the manuscript.

\section{ORCID}

William M. Roberts (iD

https://orcid.org/0000-0002-1600-3041

Marc I. Stutter (D) https://orcid.org/0000-0003-1483-376X

Philip M. Haygarth (D)

https://orcid.org/0000-0002-1672-6290

\section{REFERENCES}

Addiscott, T. M., \& Thomas, D. (2000). Tillage, mineralization and leaching: Phosphate. Soil and Tillage Research, 53, 255-273. https:// doi.org/10.1016/S0167-1987(99)00110-5

Baligar, V., Fageria, N., \& He, Z. (2001). Nutrient use efficiency in plants. Communications in Soil Science and Plant Analysis, 32, 921950. https://doi.org/10.1081/CSS-100104098

Bates, D. M. (2010). Lme4: Mixed-effects modeling with R. New York: Springer.

Bieleski, R. L. (1973). Phosphate pools, phosphate transport, and phosphate availability. Annual Review of Plant Biology, 24, 225-252. https://doi.org/10.1146/annurev.pp.24.060173.001301

Blackwell, M. S. A., Brookes, P. C., de la Fuente-Martinez, N., Gordon, H., Murray, P. J., Snars, K. E., ... Haygarth, P. M. (2010). Phosphorus solubilization and potential transfer to surface waters from the soil microbial biomass following dryingrewetting and freezing-thawing. Advances in Agronomy, 106, 1-35. https://doi.org/10.1016/S0065-2113(10)06001-3

Blevins, R. L., Thomas, G. W., \& Cornelius, P. L. (1977). Influence of no-tillage and nitrogen fertilization on certain soil properties after 5 years of continuous corn 1. Agronomy Journal, 69, 383-386. https://doi.org/10.2134/agronj1977.00021962006900030013x

Bracken, M. E. S., Hillebrand, H., Borer, E. T., Seabloom, E. W., Cebrian, J., Cleland, E. E., ... Smith, J. E. (2015). Signatures of nutrient limitation and co-limitation: Responses of autotroph internal nutrient concentrations to nitrogen and phosphorus additions. Oikos, 124, 113-121. https://doi.org/10.1111/oik.01215

Brooker, R. W., Bennett, A. E., Cong, W. F., Daniell, T. J., George, T. S., Hallett, P. D., ... White, P. J. (2015). Improving intercropping: A synthesis of research in agronomy, plant physiology and ecology. New Phytologist, 206, 107-117. https://doi.org/10.1111/nph .13132

Brown, L. K., Kazas, C., Stockan, J., Hawes, C., Stutter, M. I., Ryan, C. M., ... George, T. S. (2018). Is green manure from riparian buffer strip species an effective nutrient source for crops? Journal of Environmental Quality, 48(2), 385-393. https://doi.org/102134/ jeq2017110422
Butler, P. J., \& Haygarth, P. M. (2007). Effects of tillage and reseeding on phosphorus transfers from grassland. Soil Use and Management, 23, 71-81. https://doi.org/10.1111/j.1475-2743.2007. 00107.x

Carpenter, S. R., Caraco, N. F., Correll, D. L., Howarth, R. W., Sharpley, A. N., \& Smith, V. H. (1998). Nonpoint pollution of surface waters with phosphorus and nitrogen. Ecological Applications, 8, 559-568. https://doi.org/10.1890/1051-0761(1998)008[0559:NPOSWW]2.0. $\mathrm{CO} ; 2$

Collins, A. L., Blackwell, M. S. A., Critchley, N., Zhang, Y. S., Matthews, R. A., Williams, L. J., ... Roberts, W. M.. 2012. Improving the evidence base on riparian buffers and other options for sediment loss from agriculture: Part 1: Riparian buffer assessments (Final Report to Defra, Defra Project WQ0208). London: Department for Environment Food and Rural Affairs.

Cope, T., \& Gray, A. (2009). Grasses of the British Isles. London: Botanical Society of the British Isles.

Dinkelaker, B., Mheld, V. R. Ö., \& Marschner, H. (1989). Citric acid excretion and precipitation of calcium citrate in the rhizosphere of white lupin (Lupinus albus L). Plant, Cell and Environment, 12, 285292. https://doi.org/10.1111/j.1365-3040.1989.tb01942.x

Dorioz, J. M., Wang, D., Poulenard, J., \& Trévisan, D. (2006). The effect of grass buffer strips on phosphorus dynamics-A critical review and synthesis as a basis for application in agricultural landscapes in France. Agriculture Ecosystems and Environment, 117, 4-21. https://doi.org/10.1016/j.agee.2006.03.029

Dupas, R., Gruau, G., Gu, S., Humbert, G., Jaffrezic, A., \& GascuelOdoux, C. (2015). Groundwater control of biogeochemical processes causing phosphorus release from riparian wetlands. Water Research, 84, 307-314. https://doi.org/10.1016/j.watres.2015.07.048

Elser, J. J., Bracken, M. E. S., Cleland, E. E., Gruner, D. S., Harpole, W. S., Hillebrand, H., ... Smith, J. E. (2007). Global analysis of nitrogen and phosphorus limitation of primary producers in freshwater, marine and terrestrial ecosystems. Ecology Letters, 10, 1135-1142. https://doi.org/10.1111/j.1461-0248.2007.01113.X

Forber, K. J., Ockenden, M. C., Wearing, C., Hollaway, M. J., Falloon, P. D., Kahana, R., ... Haygarth, P. M. (2017). Determining the effect of drying time on phosphorus solubilization from three agricultural soils under climate change scenarios. Journal of Environmental Quality, 46(5), 1131-1136. https://doi.org/10.2134/jeq2017.04.0144

Fraser, L. H., Carty, S. M., \& Steer, D. (2004). A test of four plant species to reduce total nitrogen and total phosphorus from soil leachate in subsurface wetland microcosms. Bioresource Technology, 94, 185192. https://doi.org/10.1016/j.biortech.2003.11.023

Giles, C. D., George, T. S., Brown, L. K., Mezeli, M., Shand, C. A., Richardson, A. E., ... Haygarth, P. M. (2017). Linking the depletion of rhizosphere phosphorus to the heterologous expression of a fungal phytase in Nicotiana tabacum as revealed by enzymelabile P and solution 31P NMR spectroscopy. Rhizosphere, 3, 82-91. https://doi.org/10.1016/j.rhisph.2016.11.004

Godwin, C. M., \& Cotner, J. B. (2015). Stoichiometric flexibility in diverse aquatic heterotrophic bacteria is coupled to differences in cellular phosphorus quotas. Frontiers in Microbiology, 6. https://doi.org/10.3389/fmicb.2015.00159

Grinsted, M. J., Hedley, M. J., White, R. E., \& Nye, P. H. (1982). Plant-induced changes in the rhizosphere of rape (Brassica napus var. emerald) seedlings. I. $\mathrm{pH}$ changes and the increase in P concentration in the soil solution. New Phytologist, 91, 19-29. https://doi.org/ 10.1111/j.1469-8137.1982.tb03289.x 
Gu, S., Gruau, G., Malique, F., Dupas, R., Petitjean, P., \& GascuelOdoux, C. (2018). Drying/rewetting cycles stimulate release of colloidal-bound phosphorus in riparian soils. Geoderma, 321, 32-41. https://doi.org/10.1016/j.geoderma.2018.01.015

Haygarth, P. M., \& Sharpley, A. N. (2000). Terminology for phosphorus transfer. Journal of Environmental Quality, 29, 10-15. https://doi.org/10.2134/jeq2000.00472425002900010002x

Hille, S., Graeber, D., Kronvang, B., Rubæk, G. H., Onnen, N., MolinaNavarro, E., ... Stutter, M. I. (2018). Management options to reduce phosphorus leaching from vegetated buffer strips. Journal of Environmental Quality, 48(2), 322-329. https://doi.org/10.2134/ jeq2018.01.0042

Hinsinger, P. (2001). Bioavailability of soil inorganic P in the rhizosphere as affected by root-induced chemical changes: A review. Plant and Soil, 237, 173-195. https://doi.org/10.1023/A:1013351617532

Hinsinger, P., Betencourt, E., Bernard, L., Brauman, A., Plassard, C., Shen, J., ... Zhang, F. (2011). P for two, sharing a scarce resource: Soil phosphorus acquisition in the rhizosphere of intercropped species. Plant Physiology, 156, 1078-1086. https://doi.org/10.1104/ pp.111.175331

Hinsinger, P., \& Gilkes, R. J. (1997). Dissolution of phosphate rock in the rhizosphere of five plant species grown in an acid, P-fixing mineral substrate. Geoderma, 75, 231-249. https://doi.org/10.1016/S00167061(96)00094-8

Hinsinger, P., \& Gilkes, R. J. (1996). Mobilization of phosphate from phosphate rock and alumina-sorbed phosphate by the roots of ryegrass and clover as related to rhizosphere $\mathrm{pH}$. European Journal of Soil Science, 47, 533-544. https://doi.org/10.1111/ j.1365-2389.1996.tb01853.x

Hinsinger, P., \& Gilkes, R. J. (1995). Root-induced dissolution of phosphate rock in the rhizosphere of lupins grown in alkaline soil. Australian Journal of Soil Research, 33, 477-489. https://doi.org/ 10.1071/SR9950477

Hinsinger, P., Gobran, G. R., Gregory, P. J., \& Wenzel, W. W. (2005). Rhizosphere geometry and heterogeneity arising from root-mediated physical and chemical processes. New Phytologist, 168, 293-303. https://doi.org/10.1111/j.1469-8137.2005.01512.x

Hoffmann, C. C., Kjaergaard, C., Uusi-Kämppä, J., Hansen, H. C. B., \& Kronvang, B. (2009). Phosphorus retention in riparian buffers: Review of their efficiency. Journal of Environmental Quality, 38, 1942-1955. https://doi.org/10.2134/jeq2008.0087

Irving, G. C. J., \& McLaughlin, M. J. (1990). A rapid and simple field test for phosphorus in Olsen and Bray no. 1 extracts of soil. Communications in Soil Science and Plant Analysis, 21, 2245-2255. https://doi.org/10.1080/00103629009368377

Jones, D. L., Nguyen, C., \& Finlay, R. D. (2009). Carbon flow in the rhizosphere: Carbon trading at the soil-root interface. Plant and Soil, 321, 5-33. https://doi.org/10.1007/s11104-009-9925-0

Kirk, G. J. D., Santos, E. E., \& Findenegg, G. R. (1999a). Phosphate solubilization by organic anion excretion from rice (Oryza sativa L) growing in aerobic soil. Plant and Soil, 211, 11-18. https://doi.org/10.1023/A:1004539212083

Kirk, G. J. D., Santos, E. E., \& Santos, M. B. (1999b). Phosphate solubilization by organic anion excretion from rice (Oryza sativa L.) growing in aerobic soil: Rates of excretion and decomposition, effects on rhizosphere $\mathrm{pH}$ and effects on phosphate solubility and uptake. New Phytologist, 142, 185-200. https://doi.org/10.1046/ j.1469-8137.1999.00400.x
Kuzyakov, Y., \& Domanski, G. (2000). Carbon input by plants into the soil: Review. Journal of Plant Nutrition and Soil Science, 163, 421431. https://doi.org/421::Aid-jpln421>3.0.co;2-r

Leimer, S., Oelmann, Y., Wirth, C., \& Wilcke, W. (2015). Time matters for plant diversity effects on nitrate leaching from temperate grassland. Agriculture Ecosystems and Environment, 211, 155-163. https://doi.org/10.1016/j.agee.2015.06.002

Le Moal, M., Gascuel-Odoux, C., Ménesguen, A., Souchon, Y., Étrillard, C., Levain, A., ... Pinay, G. (2019). Eutrophication: A new wine in an old bottle? Science of the Total Environment, 651, 1-11. https://doi.org/10.1016/j.scitotenv.2018.09.139

Lemunyon, J. L., \& Gilbert, R. G. (1993). The concept and need for a phosphorus assessment tool. Journal of Production Agriculture, 6, 483-486. https://doi.org/10.2134/jpa1993.0483

Lovett, G. M., Weathers, K. C., \& Athur, M. A. (2002). Control of nitrogen loss from forested watersheds by soil carbon:nitrogen ratio and tree species composition. Ecosystems, 5, 712-718. https://doi.org/10.1007/s10021-002-0153-1

Lyu, Y., Tang, H., Li, H., Zhang, F., Rengel, Z., Whalley, W. R., \& Shen, J. (2016). Major crop species show differential balance between root morphological and physiological response to variable phosphorus supply. Frontiers in Plant Science, 7, 1939. https://doi.org/10.3389/ fpls.2016.01939

Marrs, R. H., Gough, M. W., \& Griffiths, M. (1991). Soil chemistry and leaching losses of nutrients from semi-natural grassland and arable soils on three contrasting parent materials. Biological Conservation, 57, 257-271. https://doi.org/10.1016/0006-3207(91)90072-H

Martin, J. K. (1971). ${ }^{14} \mathrm{C}$-Labelled material leached from the rhizosphere of plants supplied with ${ }^{14} \mathrm{CO}_{2}$. Australian Journal of Biological Sciences, 24, 1131-1142. https://doi.org/10.1071/BI9711131

Mazzoncini, M., Antichi, D., and Bene, C. Di., Risaliti, R., Petri, M., \& Bonari, E. (2016). Soil carbon and nitrogen changes after 28 years of no-tillage management under Mediterranean conditions. European Journal of Agronomy, 77, 156-165. https://doi.org/10.1016/ j.eja.2016.02.011

McDowell, R., Sharpley, A., Crush, J., \& Simmons, T. (2011). Phosphorus in pasture plants: Potential implications for phosphorus loss in surface runoff. Plant and Soil, 345, 23-35. https://doi.org/ 10.1007/s11104-010-0687-5

Menezes-Blackburn, D., Paredes, C., Zhang, H., Giles, C. D., Darch, T., Stutter, M. I., ... Haygarth, P. M. (2016). Organic acids regulation of chemical-microbial phosphorus transformations. Environmental Science \& Technology, 50, 11521-11531. https://doi.org/10.1021/ acs.est.6b03017

Mwafulirwa, L., Baggs, E. M., Russell, J., George, T., Morley, N., Sim, A., .. Paterson, E. (2016). Barley genotype influences stabilization of rhizodeposition-derived $\mathrm{C}$ and soil organic matter mineralization. Soil Biology \& Biochemistry, 95, 60-69. https://doi.org/10.1016/j.soilbio.2015.12.011

Newman, Y. C., Agyin-Birikorang, S., Adjei, M. B., Scholberg, J. M., Silveira, M. L., Vendramini, J. M. B., ... Sollenberger, L. E. (2009). Nitrogen fertilization effect on phosphorus remediation potential of three perennial warm-season forages. Agronomy Journal, 101, 1243 1248. https://doi.org/10.2134/agronj2009.0117

Peukert, S., Griffith, B. A., Murray, P. J., Macleod, C. J. A., \& Brazier, R. E. (2014). Intensive management in grasslands causes diffuse water pollution at the farm scale. Journal of Environmental Quality, 43, 2009-2023. https://doi.org/10.2134/jeq2014.04.0193 
Peukert, S., Griffith, B. A., Murray, P. J., Macleod, C. J. A., \& Brazier, R. E. (2016). Spatial variation in soil properties and diffuse losses between and within grassland fields with similar short-term management. European Journal of Soil Science, 67, 386-396.

Pinheiro, J., Bates, D., DebRoy, S., \& Sarkar, D. (2007). nlme: Linear and nonlinear mixed effects models (R Package version 3). Vienna: $\mathrm{R}$ Foundation for Statistical Computing.

Pionke, H. B., Gburek, W. J., Sharpley, A. N., \& Schnabel, R. R. (1996). Flow and nutrient export patterns for an agricultural hill-land watershed. Water Resources Research, 32, 1795-1804. https://doi.org/ 10.1029/96WR00637

Ratnayake, M., Leonard, R. T., \& Menge, J. A. (1978). Root exudation in relation to supply of phosphorus and it's possible relevance to mycorrhizal formation. New Phytologist, 81, 543-552. https://doi.org/10.1111/j.1469-8137.1978.tb01627.x

Räty, M., Uusi-Kämppä, J., Yli-Halla, M., Rasa, K., \& Pietola, L. (2010). Phosphorus and nitrogen cycles in the vegetation of differently managed buffer zones. Nutrient Cycling in Agroecosystems, 86, 121-132. https://doi.org/10.1007/s10705-009-9277-4

Richardson, A. E., Barea, J., McNeill, A., \& Prigent-Combaret, A. (2009a). Acquisition of phosphorus and nitrogen in the rhizosphere and plant growth promotion by microorganisms. Plant and Soil, 321, 305-339. https://doi.org/10.1007/s11104-009-9895-2

Richardson, A. E., Hocking, P. J., Simpson, R. J., \& George, T. S. (2009b). Plant mechanisms to optimise access to soil phosphorus. Crop and Pasture Science, 60, 124-143. https://doi.org/10.1071/ $\mathrm{CP} 07125$

Riddle, M. U., \& Bergstrőm, L. (2013). Phosphorus leaching from two soils with catch crops exposed to freeze-thaw cycles. Agronomy Journal, 105, 803-811. https://doi.org/10.2134/agronj2012.0052

Roberts, W. M. (2013). Biological phosphorus solubilisation in riparian buffer strip soils ( $\mathrm{PhD}$ thesis). Lancaster, UK: Lancaster University.

Roberts, W. M., Matthews, R. A., Blackwell, M. S. A., Peukert, S., Collins, A. L., Stutter, M. I., \& Haygarth, P. M. (2013). Microbial biomass phosphorus contributions to phosphorus solubility in riparian vegetated buffer strip soils. Biology and Fertility of Soils, 49, 1237-1241. https://doi.org/10.1007/s00374-013-0802-x

Roberts, W. M., Stutter, M. I., \& Haygarth, P. M. (2012). Phosphorus retention and remobilization in vegetated buffer strip: A review. Journal of Environmental Quality, 41, 389-399. https://doi.org/10.2134/jeq2010.0543

Rowe, H., Withers, P. J. A., Baas, P., Chan, N. I., Doody, D., Holiman, J., ... Weintraub, M. N. (2016). Integrating legacy soil phosphorus into sustainable nutrient management strategies for future food, bioenergy and water security. Nutrient Cycling in Agroecosystems, 104, 393 412. https://doi.org/10.1007/s10705-015-9726-1

Schachtman, D. P., Reid, R. J., \& Ayling, S. M. (1998). Phosphorus uptake by plants: From soil to cell. Plant Physiology, 116, 447-453. https://doi.org/10.1104/pp.116.2.447

Scherer-Lorenzen, M., Palmborg, C., Prinz, A., \& Schulze, E.-D. (2003). The role of plant diversity and composition for nitrate leaching in grasslands. Ecology, 84, 1539-1552. https://doi.org/ 10.1890/0012-9658(2003)084[1539:TROPDA]2.0.CO;2

Schulte, R. P. O., Melland, A. R., Fenton, O., Herlihy, M., Richards, K., \& Jordan, P. (2010). Modelling soil phosphorus decline: Expectations of Water Framework Directive policies. Environmental Science \& Policy, 13, 472-484. https://doi.org/10.1016/j.envsci.2010.06.002

Selles, F., Campbell, C. A., Zentner, R. P., Curtin, D., James, D. C., \& Basnyat, P. (2011). Phosphorus use efficiency and long-term trends in soil available phosphorus in wheat production systems with and without nitrogen fertilizer. Canadian Journal of Soil Science, 91, 3952. https://doi.org/10.4141/cjss10049

Soil Survey of England and Wales. (1983). Soil map of England and Wales [Scale: 1:250000]. Southampton, UK: Ordnance Survey.

Sovik, A. K., \& Syversen, N. (2008). Retention of particles and nutrients in the root zone of a vegetated buffer zone: Effect of vegetation and season. Boreal Environment Research, 13, 223-230.

Stutter, M. I., Graeber, D., Evans, C. D., Wade, W. J., \& Withers, P. J. A. (2018). Balancing macronutrient stoichiometry to alleviate eutrophication. Science of the Total Environment, 634, 439-447. https://doi.org/10.1016/j.scitotenv.2018.03.298

Stutter, M. I., \& Richards, S. (2012). Relationships between soil physicochemical, microbiological properties, and nutrient release in buffer soils compared to field soils. Journal of Environmental Quality, 41(2), 400-409. https://doi.org/10.2134/jeq2010.0456

Stutter, M. I., Shand, C. A., George, T. S., Blackwell, M. S. A., Dixon, L., Bol, R., ... Haygarth, P. M. (2015). Land use and soil factors affecting accumulation of phosphorus species in temperate soils. Geoderma, 257-258, 29-39. https://doi.org/10.1016/j.geoderma.2015.03.020

Syversen, N., \& Haarstad, K. (2005). Retention of pesticides and nutrients in a vegetated root zone compared to soil with low biological activity. International Journal of Environmental Analytical Chemistry, 85, 1175-1187. https://doi.org/10.1080/03067310500117400

Turner, B. L., Baxter, R., \& Whitton, B. A. (2003). Nitrogen and phosphorus in soil solutions and drainage streams in Upper Teesdale, northern England: Implications of organic compounds for biological nutrient limitation. Science of the Total Environment, 314-316, 153-170. https://doi.org/10.1016/S0048-9697(03)00101-3

Ulén, B., \& Etana, A. (2010). Risk of phosphorus leaching from low input grassland areas. Geoderma, 158, 359-365. https://doi.org/ 10.1016/j.geoderma.2010.06.003

Uusi-Kämppä, J. (2005). Phosphorus purification in buffer zones in cold climates. Ecological Engineering, 24, 491-502. https://doi.org/ 10.1016/j.ecoleng.2005.01.013

Walker, T. S., Bais, H. P., Grotewold, E., \& Vivanco, J. M. (2003). Root exudation and rhizosphere biology. Plant Physiology, 132, 44-51. https://doi.org/10.1104/pp.102.019661

Zhang, Y., Collins, A. L., Murdoch, N., Lee, D., \& Naden, P. S. (2014). Cross sector contributions to river pollution in England and Wales: Updating waterbody scale information to support policy delivery for the Water Framework Directive. Environmental Science \& Policy, 42, 16-32. https://doi.org/10.1016/j.envsci.2014.04.010

\section{SUPPORTING INFORMATION}

Additional supporting information may be found online in the Supporting Information section at the end of the article.

How to cite this article: Roberts WM, George TS, Stutter MI, Louro A, Ali M, Haygarth PM.

Phosphorus leaching from riparian soils with differing management histories under three grass species.

J. Environ. Qual. 2020;49:74-84.

https://doi.org/10.1002/jeq2.20037 